\title{
The Incidence, Predisposing Factors, Complications and Outcome of Preeclampsia in Diabetic Pregnancy
}

\author{
JESMIN $\mathrm{S}^{\mathrm{a}}$, JAHAN $\mathrm{S}^{\mathrm{a}}$, KHAN M I ${ }^{\mathrm{a}}$, SULTANA N ${ }^{\mathrm{a}}$, JERIN J ${ }^{\mathrm{a}}$, HABIB SH ${ }^{\mathrm{b}}$, PAUL ${ }^{\mathrm{c}}$
}

\begin{abstract}
Introduction: Preeclampsia is a serious complication of pregnancy and common cause of fetal and maternal morbidity as well as mortality worldwide. In diabetic women, the chance of preeclampsia is increased. The incidence of preeclampsia in diabetic pregnancy is approximately 10 to 15 percent, which is associated with poor glycaemic control. Aim: This study was carried out to find the predisposing factors related to preeclampsia and determine the complications of preeclampsia in diabetic pregnancy and also the impact of preeclampsia in infants born to diabetic mothers. Methods: This prospective study was carried out at the Bangladesh Institute of Research and Rehabilitation in Diabetes, Endocrine and Metabolic Disorders (BIRDEM), Dhaka. The Patient population consisted of 80 diabetic pregnant women who attended or admitted to BIRDEM hospital during the study period. The women were divided into groups: 50 pregnant diabetic women with preeclampsia were taken as case. 30 pregnant diabetic women without preeclampsia were taken as control. Diagnosis of preeclampsia was made on the basis of the criteria of the Committee on Terminology of the American College of Obstetrician and Gynecologist. Results: Preterm delivery (<37 weeks gestation) was higher among study group (64\%) compared to control (33.3\%) women. Term delivery was 36.0 vs 66.7 percent among case and control women, respectively. The distribution is statistically significant $(P<0.01)$. 35 percent of Caesarean section was
\end{abstract}

Introduction:

Pregnancy is a great stressful physiological condition in women during their reproductive period. Diabetes mellitus is an important medical disorders in pregnancy, which is an important associated risk factors for mother

a. Jesmin S, Jahan S, Khan M I, Sultana N, Jerin J, Department of Gynaecology and Obstetrics, BIRDEM, Dhaka, Bangladesh;

b. Habib SH, Health Economics Unit, BADAS, Dhaka, Bangladesh

c. Paul D, Department of Biochemistry and Cell Biology, Biomedical Research Group, BIRDEM, Dhaka, Bangladesh.

Address of Correspondence: Dr. Suha Jesmin, Department of Gynaecology and Obstetrics, 122, Kazi Nazrul Islam Avenue, BIRDEM, Dhaka, Bangladesh, Phone no. 008802 8616641-50 ex2468; Cell no. 01817049292

Received: May 16, 2011

Accepted: June 26, 2011 done due to fetal distress in the study group and in control group it was 20 percent. In study group, 22.5 percent Caesarean sections were done due to impending eclampsia and eclampsia, 705 percent due to accidental haemorrhage and 5 percent due to IUGR. Maternal complication in study and control subjects. In the case group, maximum number of the women (16\%) showed signs of impending eclampsia, while among control women, maximum number (10\%) developed postpartum haemorrhage ( $\mathrm{PPH}) .48$ percent neonates were of low birth weight and in controls it was 13.3 percent. Both hyperbilirubinaemia (40\%) and hypoglycaemia (30\%) were more in study group than controls (16.66\% and 20\%, respectively). Perinatal outcome among study group and controls. Neonatal survival was 82.0 percent in study group and 86.7 percent in control group. Comparison of Perinatal outcome between the groups is not statistically significant. Most of the perinatal mortality was due to prematurity (8\%) and intrauterine death (6\%). In control group, most of the perinatal deaths were due to congenital anomalies (6.6\%). Conclusion: The higher incidence among study group may be, in part, the result of more preterm birth or shortened gestational duration because early delivery is a consequence of preeclampsia. The higher rate in associated with preeclampsia was due to increased incidence of IUD and prematurity.

Key Words: Incidence, Predisposing Factors, Complications, Preeclampsia, Diabetic Pregnancy

(Birdem Med J 2011; 1(1): 10-14)

and the fetus during current pregnancy and also has serious implications for their long-term well being.

Glycaemic control is critical during pregnancy, and the benefits may result in a viable, healthy offspring. Pregnancy combined with diabetes is a period when a patient can readily see the result of benefits as a consequence of glycaemic control and attention to diabetes care. Preeclampsia is a serious complication of pregnancy and common cause of fetal and maternal morbidity as well as mortality worldwide.

In our country, preeclampsia and eclampsia are leading causes of maternal mortality. ${ }^{1}$ In diabetic subjects, there is a increased chance of preeclampsia, (which cause high blood pressure, swelling in body and appearance of 
protein in urine) which leads to serious complications if not treated promptly. The incidence of preeclampsia in diabetic pregnancy is approximately 10 to 15 percent, which is associated with poor glycaemic control ${ }^{2}$. Proper antenatal check-up and early diagnosis of preeclampsia in diabetic women, prompt treatment and strict control of blood sugar may reduce the complications of diabetic preeclampsia.

This study was carried out to find the predisposing factors related to preeclampsia and determine the complications of preeclampsia in diabetic pregnancy and also the impact of preeclampsia in infants born to diabetic mothers.

\section{Materials and Methods:}

This prospective study was carried out at the Bangladesh Institute of Research and Rehabilitation in Diabetes, Endocrine and Metabolic Disorders (BIRDEM), Dhaka.

The Patient population consisted of 80 diabetic pregnant women who attended or admitted to BIRDEM hospital during the study period. The women were divided into groups:

a) 50 pregnant diabetic women with preeclampsia were taken as case.

b) 30 pregnant diabetic women without preeclampsia were taken as control.

The inclusion criteria for the case were as follows; Gestational protinuric hypertension, Patients with increased systolic blood pressure of $\geq 30 \mathrm{mmHg}$ or diastolic $\geq 15 \mathrm{mmHg}$ over a baseline blood pressure after 20 weeks of gestation, Blood Pressure of $\geq 140 / 90$ mmHg at least on two measurements taken 6 hours apart after 20 weeks of pregnancy if prior blood pressure is not known, Preconception diabetic women, Gestational diabetic women
The exclusion criteria for the case were as follows; History of Gestational hypertension without protinuria, Diabetes and Preeclampsia toxaemia (PET) with other systemic disease like congestive cardiac failure, chronic liver disease, endocrinopathy and autoimmune disease.

\section{Method:}

Diagnosis of preeclampsia was made on the basis of the criteria of the Committee on Terminology of the American College of Obstetrician and Gynecologist. ${ }^{3}$

Blood pressure measurement was taken with the patient in sitting position with right in a roughly horizontal position at heart level. Blood pressure measurement was done every two weeks from 28 to 36 weeks and weekly from 36 weeks gestation up to delivery.

Serial measurement of serum uric acid, creatinine and blood urea levels were done. Diagnosis of gestational diabetes was madder on the basis of WHO criteria.

The diabetic patients were managed with dietary regulation and intensified by subcutaneous insulin therapy with goals to maintain fasting blood glucose level at $<105$ $\mathrm{mg} / \mathrm{dl}$ and postprandial glucose $<140 \mathrm{mg} / \mathrm{dl}$.

\section{Statistical Analysis:}

Relevant data of each of the study subjects were recorded on a predesigned data collection sheet. Data were complied and appropriate statistical analyses were done using computer based software, Statistical Package for Social Science (SPSS).

\section{Results:}

Table I shows that 12.0 percent study group and 6.7 percent control subjects had Oligohydramnios, 6.0 percent case and 13.3 percent control subjects had polyhydramnios and 82.0 percent case and 80.0 percent control subjects had adequate volume of liquor amnii. Liquor volume did not shoe any statistical difference between the two groups.

Table I

Volume of liquor amnii in study and control subjects:

\begin{tabular}{lccc} 
Liquor amnii & Case (n=50) & Control (n=30) & P value $^{\mathrm{a}}$ \\
& No. (\%) & No. (\%) & \\
\hline Oligohydramnios & $6(12.0)$ & $2(6.7)$ & \\
Polyhydramnios & $3(6.0)$ & $4(13.3)$ & 0.428 NS \\
Adequate & $41(82.0)$ & $24(80.0)$ & \\
\hline
\end{tabular}

${ }^{\mathrm{a} C h i}$-square test, ${ }^{\mathrm{NS}}$ Not significant 
In study group, 80percent and in control group, 66.7 percent were delivered by LUCS which is statistically significant $(\mathrm{P}<0.001)$ and 20.0 percent in study group and 33.3 percent in control group had normal vaginal delivery which is statistically significant $(\mathrm{P}<0.01)$.

Table II

\begin{tabular}{|c|c|c|c|}
\hline \multicolumn{4}{|c|}{ Mode of delivery in study and control subjects: } \\
\hline Mode of Delivery & $\begin{array}{l}\text { Case } \\
(\mathrm{n}=50)\end{array}$ & $\begin{array}{l}\text { Control } \\
(\mathrm{n}=30)\end{array}$ & $\begin{array}{c}\mathrm{P} \\
\text { value }^{\mathrm{a}}\end{array}$ \\
\hline & No. (\%) & No. (\%) & \\
\hline $\begin{array}{l}\text { LUCS (Lower Uterine } \\
\text { Caesarean Section) }\end{array}$ & $40(80.0)$ & $20(66.7)$ & $0.000^{* * *}$ \\
\hline $\begin{array}{l}\text { NVD (Normal Vaginal } \\
\text { Delivery) }\end{array}$ & $10(20.0)$ & 10 (33.3) & $0.002^{* *}$ \\
\hline
\end{tabular}

${ }^{a} \mathrm{Z}$-test, **Significant at $\mathrm{P}<0.01, * * *$ Significant at $\mathrm{P}<0.001$

Table III shows that preterm delivery $(<37$ weeks gestation) was higher among study group (64\%) compared to control (33.3\%) women. Term delivery was 36.0 vs 66.7 percent among case and control women, respectively. The distribution is statistically significant $(\mathrm{P}<0.01)$.

\section{Table III}

\begin{tabular}{|c|c|c|c|}
\hline \multicolumn{4}{|c|}{$\begin{array}{c}\text { Incidence of preterm delivery in study and control } \\
\text { subjects: }\end{array}$} \\
\hline Delivery & $\begin{array}{l}\text { Case } \\
(\mathrm{n}=50)\end{array}$ & $\begin{array}{l}\text { Control } \\
(\mathrm{n}=30)\end{array}$ & $\begin{array}{c}\mathrm{P} \\
\text { value }^{\mathrm{a}}\end{array}$ \\
\hline & No. (\%) & No. (\%) & \\
\hline Preterm & $32(64.0)$ & 10 (33.3) & $<0.01 * *$ \\
\hline Term & $18(36.0)$ & 20 (66.7) & \\
\hline
\end{tabular}

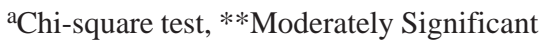

Table IV shows that 35 percent of Caesarean section was done due to fetal distress in the study group and in control group it was 20 percent. In study group, 22.5 percent Caesarean sections were done due to impending eclampsia and eclampsia, 705 percent due to accidental haemorrhage and 5 percent due to IUGR.

\section{Table IV}

Indication of Caesarean section among study group and control subjects

\begin{tabular}{lcc}
\hline Indications & $\begin{array}{c}\text { Case } \\
(\mathrm{n}=40) \\
\text { No. }(\%)\end{array}$ & $\begin{array}{c}\text { Control } \\
(\mathrm{n}=20) \\
\text { No. }(\%)\end{array}$ \\
\hline Impending eclampsia & $8(20.0)$ & 0 \\
Eclampsia & $1(2.5)$ & 0 \\
Fetal distress & $14(35.0)$ & $4(20.0)$ \\
History of previous & $4(10.0)$ & $3(15.0)$ \\
Caesarean section & & \\
Failed induction & $4(10.0)$ & $5(25.0)$ \\
Malpresentation & $2(5.0)$ & $2(10.0)$ \\
Accidental haemorrhage & $3(7.5)$ & 0 \\
IUGR & $2(5.0)$ & 0 \\
Bad obstetric history & $2(5.0)$ & $2(10.0)$ \\
Macrosomia & 0 & $4(20.0)$ \\
\hline
\end{tabular}

Table V shows maternal complication in study and control subjects. In the case group, maximum number of the women (16\%) showed signs of impending eclampsia, while among control women, maximum number (10\%) developed postpartum haemorrhage (PPH).

Table-V

\begin{tabular}{lcc}
\multicolumn{3}{l}{$\begin{array}{c}\text { Maternal Complication in study group and control } \\
\text { subjects }\end{array}$} \\
Complications & $\begin{array}{c}\text { Case } \\
(\mathrm{n}=50)\end{array}$ & $\begin{array}{c}\text { Control } \\
(\mathrm{n}=30)\end{array}$ \\
& No. (\%) & No. (\%) \\
\hline Impending eclampsia & $8(16.0)$ & - \\
Eclampsia & $1(2.0)$ & - \\
Accidental haemorrhage & $3(6.0)$ & $1(3.3)$ \\
DIC & $2(4.0)$ & - \\
Cerebrovascular accident & 0 & - \\
HELLP syndrome & $6(6.0)$ & - \\
PPH & $2(4.0)$ & $3(10.0)$ \\
Wound infection & $3(6.0)$ & $2(6.6)$ \\
\hline
\end{tabular}

Table VI shows 48 percent neonates were of low birth weight and in controls it was 13.3 percent. Both hyperbilirubinaemia (40\%) and hypoglycaemia (30\%) were more in study group than controls $(16.66 \%$ and $20 \%$, respectively). 


\section{Table VI}

Perinatal morbidity in study group and control subjects

\begin{tabular}{|c|c|c|}
\hline Morbidity & $\begin{array}{c}\text { Case } \\
(\mathrm{n}=50) \\
\text { No. }(\%)\end{array}$ & $\begin{array}{c}\text { Control } \\
(\mathrm{n}=30) \\
\text { No. }(\%)\end{array}$ \\
\hline Low birth weight & $24(48.0)$ & $4(13.3)$ \\
\hline $\begin{array}{l}\text { Intrauterine growth retardation } \\
\text { (IUGR) }\end{array}$ & $8(16.0)$ & $1(3.3)$ \\
\hline Birth asphyxia & $6(12.0)$ & $2(6.6)$ \\
\hline $\begin{array}{l}\text { Respiratory distress syndrome } \\
\text { (RDS) }\end{array}$ & $7(14.0)$ & $2(6.6)$ \\
\hline Hyperbilirubinaemia & $20(40.0)$ & $5(16.6)$ \\
\hline Hypoglycaemia & $15(30.0)$ & $6(20.0)$ \\
\hline Septicaemia & $3(6.0)$ & 0 \\
\hline Congenital anomaly & $3(6.0)$ & $1(6.6)$ \\
\hline
\end{tabular}

Table VII shows perinatal outcome among study group and controls. Neonatal survival was 82.0 percent in study group and 86.7 percent in control group. Comparison of Perinatal outcome between the groups is not statistically significant.

Table VII

\begin{tabular}{lccc}
\multicolumn{4}{c}{ Neonatal outcome in study group and control subjects } \\
Perinatal outcome & $\begin{array}{c}\text { Case } \\
(\mathrm{n}=50)\end{array}$ & $\begin{array}{c}\text { Control } \\
(\mathrm{n}=30)\end{array}$ & $\begin{array}{c}\mathrm{P} \\
\text { value }^{\mathrm{a}}\end{array}$ \\
& No. $(\%)$ & No. $(\%)$ & \\
\hline Survived & $41(82.0)$ & $26(86.7)$ & $0.584^{\mathrm{NS}}$ \\
Expired & $9(18.0)$ & $4(13.3)$ & \\
\hline
\end{tabular}

${ }^{a}$ Chi-square test,

${ }^{\mathrm{NS}}$ Not significant

Here shows that in the study group, most of the perinatal mortality was due to prematurity (8\%) and intrauterine death (6\%). In control group, most of the perinatal deaths were due to congenital anomalies (6.6\%).

\section{Table VIII}

Causes of Perinatal mortality

\begin{tabular}{lcc} 
Causes & $\begin{array}{c}\text { Case }(\mathrm{n}=50) \\
\text { No. }(\%)\end{array}$ & $\begin{array}{c}\text { Control }(\mathrm{n}=30) \\
\text { No. }(\%)\end{array}$ \\
\hline Congenital anomaly & $2(4.0)$ & $2(6.6)$ \\
Intrauterine death & $3(6.0)$ & $1(3.3)$ \\
Prematurity & $4(8.0)$ & $1(3.3)$ \\
\hline
\end{tabular}

\section{Discussion:}

Preeclampsia is a serious complication of pregnancy. Diabetes and pregnancy may affect each other over a range of interaction from conception to delivery and possibly even later. Pregnant women with diabetes have as increased risk of developing preeclampsia. The incidence of preeclampsia in diabetic patients in this study was $10.82 \%$, which correlates with that Garner et $\mathrm{al}^{3}(9.9 \%)$ and Arias $^{2}$ (10-15\%). The vascular endothelial dysfunction associated with diabetes mellitus may contribute to the increased incidence of preeclampsia among diabetic women ${ }^{5}$.

Thirty- four percent cases had family history of hypertension, which is nearly similar to the findings of Hossain ${ }^{4}(39 \%)$. The rate of preeclampsia increases significantly with the increase in severity of diabetes. Several studies have reported an association between maternal glycaemic control and adverse outcome, such as preeclampsia, preterm delivery etc ${ }^{6}$. In this study, 64 percent cases had poor glycaemic control, mostly in their half of pregnancy, which may be due to late diagnosis.

Significantly more women delivered by Caesearean section in the study group (80\%) than in the control group $(66.6 \%)(\mathrm{P}<0.001)$. The higher incidence is mostly due to early termination of pregnancy due to maternal and fetal complications. The rate Caesarean section in control group was 66.6 percent, which is similar to the findings of Khatun ${ }^{7}$ (65\%), but higher than reported by Rokshana ${ }^{\mathbf{8}}(57.45 \%)$.

The diabetic women with preeclampsia have a significant higher rate of preterm deliveries. In this study, the rate of preterm ( $<37$ week gestation) was 64 percent, which is slightly higher than Sibai et al ${ }^{6}$ (57\%). In diabetic pregnancy without preeclampsia (control), preterm delivery was33.3 percent and according to Sibai et al, it was 2704 percent. Other compliocations found in study group were impending eclampsia (16\%), eclampsia (2\%), DIC (4\%), HELLP syndrome (6\%), accidental haemorrhage (6\%) which was due to associated preeclampsia. Wound infection occurred possibly due to uncontrolled blood sugar.

The neonates of mother with preeclampsia (study group), in addition to having the threats associated with prematurely, are often compromised as a result of uteroplacental insufficiency. Marker of such chronic intrauterine comprise include intrauterine growth 
retardation (IUGR) and oligohydramnios. In this study, in the control group, the incidence of IUGR was 3.3 percent which coincides with the findings of Sibai et al ${ }^{6}$ (5.4\%). It may be due to poor control of hypertension and associated in controlled blood sugar.

In the present study, oligohydramnios was percent in 12 percent cases. It may be due to associated IUGR and placental insufficiency. In control group, oilgohydramnios was present in $6.7 \%$ women and polyhydramnios in 13.3 percent cases, which coincides with the study of Rokshana ${ }^{\mathbf{8}}$ (12.77\%).

Mother with preeclampsia usually has low-birth-weight babies. In this study, among control subjects, 13.3 percent had low-birth-weight babies, and in study subjects, the rate was 48 percent.

In the study group, 30 percent neonates developed hypoglycaemia, percent hyperbilirubinaemia, 12 percent RDS, 14 percent birth asphyxia and 6 percent septicaemia. In control group, 16.6 percent neonate's developed hyperbiliribinaemia, 20 percent developed hypoglycaemia and 6.6 percent each developed RDS and asphyxia. The higher incidence in study group may be due to prematurity. Because of hepatic insufficiency, hyperbilirubinaemia may occur in preterm babies. RDS and birth asphyxia are common complications of preterm birth. Septicaemia may occur to less protective passive immunity ${ }^{\mathbf{9}}$.

Congenital anomalies occurred in study group in 4 percent and in control group in 6.6 percent, which is almost similar to the findings by Rokshana ${ }^{8}$ (4.6\%). Incidence of IUD in study group is slightly higher (6\%) than control group (3.3\%). In present study, perinatal mortality rate was 18 percent in study group and 13.2 percent in control group, which is similar to the findings of Khatun ${ }^{7}(14.29 \%)$.

\section{Conclusion:}

The higher incidence among study group may be, in part be, in part, the result of more preterm birth or shortened gestational duration because early delivery is a consequence of preeclampsia. The higher rate in associated with preeclampsia was due to increased incidence of IUD and prematurity.

\section{References:}

1. Begum MT, Begum A, Quadir E, Akhter S, Shamsuddin L, Eclampsia: Still a Problem in Bangladesh Med Gen Med. 2004; 6(4): 52.

2. Arias F. Practical guide to high-risk pregnancy and delivery. $2^{\text {nd }}$ ed. Harcourt Brace and Company, Asia Pte. Ltd., 1992: 185-204, 280-86.

3. Barrett M. Schroeder Practice Guidelines. ACOG Practice Bulletin on Diagnosing and Managing Preeclampsia and Eclampsia. Am Fam Physician. 2002 Jul 15;66(2):330-31.

4. Garner PR, D’Alton ME, Dudley DK. Pereclampsia in diabetic pregnancies. Am J Obstet Gynecol 1990; 163: 505-8.

5. Knock GA, McCarthy AL, Lowy C, Poston L. Association of gestational diabetes with abnormal maternal vascular endothelial function. Br J Obstet Gynaecol 1997; 104: 229-34.

6. Sibai BM. Risk of preeclampsia and adverse neonatal outcome among women with pregestational diabetes mellitus. Am J Obstet Gynecol 2000; 182: 366-68.

7. Khatun F. The study of pregnancy outcome in non-insulin dependent and geatational diabetes mellitus (dissertation). Dhaka: Bangladesh College of Physicians and Surgeons, 1996.

8. Rokshana I. Management and outcome of pregnancy with diabetes mellitus (dissertation). Dhaka: Bangladesh College of Physicians and Surgeons, 1994.

9. Dutta DC. Textbook of obstetrics. $5^{\text {th }}$ ed. New Central Book Agency, 2001: 490-501. 